\title{
A trienone analog of curcumin, 1,7-bis (3-hydroxyphenyl)-1,4,6-heptatrien-3-one, possesses ROS- and caspase-mediated apoptosis in human oral squamous cell carcinoma cells in vitro
}

\author{
Tanyarath Utaipan ${ }^{1 *}$,, Piyawan Boonyanuphong2, Thipphawan Chuprajob ${ }^{3,4}$, Apichart Suksamrarn $^{3}$ \\ and Warangkana Chunglok ${ }^{5}$
}

\begin{abstract}
The leading causes of oral cancer treatment failure are cancer metastasis and chemotherapeutic resistance. Thus, developing novel anticancer agents that are effective against those aggressive cancer cells would be important for complementary or alternative treatments. The objective of this study was to investigate cytotoxicity and anticancer mechanisms of a synthetic trienone analog of curcumin, 1,7-bis(3-hydroxyphenyl)-1,4,6-heptatrien-3-one (trienone 11), against human oral squamous cell carcinoma (OSCC) cells exhibiting multidrug resistance (CLS-354/DX). The study of cytotoxicity showed that trienone $\mathbf{1 1}$ exerted threefold stronger cytotoxicity to CLS-354/DX cells than curcumin. Trienone 11 (15-30 $\mu \mathrm{M}$ ) markedly induced intracellular reactive oxygen species (ROS) resulting in apoptotic cell death within $24 \mathrm{~h}$, through activation of caspase-3/7 and caspase-9. A ROS inhibitor, N-acetylcysteine (NAC) prevented apoptotic cell death via decreasing caspase activation. Thus, the cytotoxicity of trienone $\mathbf{1 1}$ against CLS354/DX cells was ROS-mediated intrinsic apoptosis. Overall, trienone 11 could be an interesting lead for developing anti-cancer agents against multidrug resistant OSCC cells.
\end{abstract}

Keywords: Trienone, Curcumin analog, Cytotoxicity, Human mouth squamous cell carcinoma cells, Reactive oxygen species, Apoptosis

\section{Introduction}

Oral squamous cell carcinoma (OSCC) is particularly serious because this cancer type is often diagnosed when cancer metastasizes in its late stages [1,2]. Late-stage cancer cells are rendered more resistant to chemotherapy by altering biological factors such as drug transportation, metabolic reprogramming, redox status, and DNA repair that may contribute to treatment failure [3, 4]. During the

\footnotetext{
*Correspondence: tanyarath.ut@gmail.com

${ }^{1}$ Department of Pre-Clinic, Faculty of Science and Technology, Prince

of Songkla University, Pattani Campus, Pattani 94000, Thailand

Full list of author information is available at the end of the article
}

last few decades, extensive studies have examined new strategies to overcome multidrug-resistant cancer cells by restraining their escape via resistance mechanisms through the use of novel anticancer drugs [5]. Currently, new anticancer agents have been developed by structurally modifying a natural compound to create analogs or derivatives with increased anticancer efficacy and relatively weak side effects [6].

Curcumin, a major chemical constituent isolated from the rhizome of turmeric (Curcuma longa L.), has demonstrated broad-spectrum anti-inflammatory [7], antioxidant [8], and anticancer activities [9]. Curcumin exerts anticancer effects against various types of cancer 
by interacting with multiple intracellular proteins including transcription factors that potentiate the expression of multiple genes [10]. Thus, curcumin is a popular lead compound for new drug development [9]. However, the use of curcumin is restricted by poor bioavailability, stability, solubility, and absorption [11, 12]. Synthetic curcuminoid derivatives have, therefore, been developed by modifying the parent structure to improve anticancer potency. These analogs include DK1 [13], B63 [14], EF24 [15], WZ35 [16], and those with 1,4,6-trien-one function or trienones [17].

Trienone is a rare naturally occurring curcuminoid analog; its biological activities have not been comprehensively investigated. The 1,7-bis(4-hydroxyphenyl)1,4,6-heptatrien-3-one (trienone 4 ) is a minor naturally occurring analog of curcumin that was initially isolated from C. domestica Val. [18]. Trienone $\mathbf{4}$ has been reported to exert anti-peroxidation [19] and anti-inflammatory activity [20], together with cytotoxicity against melanoma cells [21]. Recently, we demonstrated the successful synthesis of trienone $\mathbf{4}$ and its analogs in the laboratory to replace natural trienones for cytotoxicity evaluation in the KB cell line. Our results determined that a new trienone analog, 1,7-bis(3-hydroxyphenyl)1,4,6-heptatrien-3-one (trienone 11), exerted interesting cytotoxicity against the KB cell line with a very high selectivity index, suggesting potential for anticancer activity [17]. However, the exact cytotoxic mechanism of trienone 11 remains unclear and further investigation of other cancer cell types is required.

Here, the underlying anticancer activity mechanism against the multidrug-resistant human OSCC cell line (CLS-354/DX) of trienone 11 was investigated. Potency against CLS-354/DX cells of trienone $\mathbf{1 1}$ was compared with curcumin and trienone 4 , while mechanisms of cytotoxicity including apoptosis induction, reactive oxygen species (ROS) production, and caspase activation were also assessed. We proposed that trienone $\mathbf{1 1}$ is a promising candidate for developing agents against multidrug-resistant OSCCs.

\section{Materials and methods}

Curcumin, trienone, and trienone analog of curcuminoids

Curcumin was isolated from the rhizomes of $C$. longa as described previously [22]. The trienones 4 and 11 were synthesized and characterized by the literature method [17] (Fig. 1). The NMR spectra of these compounds are presented in Additional file 1. All these compounds were dissolved in dimethyl sulfoxide (DMSO) before use.

\section{Cell lines and cell culture reagents}

CLS-354/WT and CLS-354/DX cell lines were established from human OSCC cell line CLS-354 (CLS Cell line service, $\mathrm{GmbH}$, Eppellheim, Germany) as has been described earlier [23, 24]. A monkey kidney epithelial cell line (Vero) was purchased from CLS Cell line service (GmbH, Eppellheim, Germany). All cell culture media and supplementary reagents were purchased from Gibco, Life Technology, USA. All cell culture materials were purchased from Nest Biotechnology, China.

\section{Cell culture}

CLS-354/DX, CLS-354/WT, and Vero cells were cultured in sterile conditions in RPMI-1640 supplemented with $10 \%$ fetal bovine serum, $1 \%$ penicillin/streptomycin, and $2 \mathrm{mM}$ L-glutamine. The cells were maintained in a $\mathrm{CO}_{2}$ incubator with $5 \% \mathrm{CO}_{2}$ and $95 \%$ humidity at $37^{\circ} \mathrm{C}$. Cell culture media were changed every 2 days in a sterile manner. The cells were sub-cultured when confluency was reached to $80 \%$ using 1:4 split ratio.

\section{Cytotoxicity test}

Cells were seeded in 96-well plates at a density of $1.0 \times 10^{4}$ cells $/ 0.32 \mathrm{~cm}^{2}$. The cells were grown for $48 \mathrm{~h}$ before treatment to reach confluency at $70 \%$. Curcumin, trienone $\mathbf{4}$, and trienone $\mathbf{1 1}$ solutions were diluted in<smiles>COc1cc(/C=C/C(=O)/C=C(O)/C=C/c2ccc(O)c(OC)c2)ccc1O</smiles><smiles>O=C(/C=C/C=C/c1ccc(O)cc1)/C=C/c1ccc(O)cc1</smiles><smiles>O=C(/C=C/C=C/c1cccc(O)c1)/C=C/c1cccc(O)c1</smiles>

Fig. 1 Structures of curcumin $(\mathbf{a})$, trienone $\mathbf{4}(\mathbf{b})$, and trienone $\mathbf{1 1}$ (c) determined by NMR $\left({ }^{1} \mathrm{H}\right.$ and ${ }^{13} \mathrm{C} \mathrm{NMR}$, and $2 \mathrm{D} C O S Y, H M Q C$ and $\left.\mathrm{HMBC}\right)$ and mass spectroscopy 
complete RPMI-1640 to obtain a final concentration at $80 \mu \mathrm{M}$, and then serially diluted to $5 \mu \mathrm{M}$. The cells were treated with the compounds for $24 \mathrm{~h}$. In some experiments, the cells were pre-incubated with $5 \mathrm{mM} \mathrm{N}$-acetyl cysteine (NAC, Sigma-Aldrich Corp., St. Louis, MO, USA) for $1 \mathrm{~h}$, followed by treatment with trienone $\mathbf{1 1}$ at various concentrations for $24 \mathrm{~h}$ in order to evaluate ROS-mediated cytotoxicity. After the 24 h-treatment, the spent media were removed, $200 \mu \mathrm{l}$ of $0.5 \mathrm{mg} / \mathrm{ml}$ 3-(4,5dimethylthiazol-2-yl)-2,5-diphenyltetrazolium bromide (MTT; Invitrogen, Life Technologies, USA) solution was added to each well and incubated for $4 \mathrm{~h}$. The formazan crystals were dissolved in DMSO. The absorbance (Abs) was detected at $560 \mathrm{~nm}$ and background at $670 \mathrm{~nm}$ was subtracted, using a microplate reader [23]. Cell viability was calculated as follows:

$$
\% \text { Cell viability }=\left(\frac{\text { Abs.treated }}{\text { Abs.untreated }}\right) \times 100
$$

\section{Determination of half maximal inhibitory concentration $\left(\mathrm{IC}_{50}\right)$ and selectivity index (SI)}

$\mathrm{IC}_{50}$ was determined from a dose response curve (inhibitory effect) using Graphpad Prism 6.0 (Graphpad Software Inc., USA). Selectivity index (SI) was calculated by comparing $\mathrm{IC}_{50}$ values for the CLS-354/DX or CLS-354/ WT cell lines against the $\mathrm{IC}_{50}$ of the same compound in a cell line of non-cancerous cells [25].

\section{Measurement of intracellular ROS}

Cells were seeded at $4.2 \times 10^{4} / \mathrm{cm}^{2}$ in a 6-well plate cultured for $48 \mathrm{~h}$. The cells were treated with trienone $\mathbf{1 1}$ at various concentrations for $12 \mathrm{~h}$. In some experiments, the cells were pre-treated with NAC for $1 \mathrm{~h}$, followed by trienone $\mathbf{1 1}$ for $12 \mathrm{~h}$. Intracellular ROS generation was monitored by a flow cytometer using the peroxidesensitive fluorescent probe $2^{\prime}, 7^{\prime}$-dichlorofluorescin diacetate $\left(\mathrm{H}_{2} \mathrm{DCFDA}\right)$ as previously described [26]. In brief, after the incubation, cells were harvested, centrifuged at $1500 \mathrm{rpm}$ for $5 \mathrm{~min}$, and washed with phosphate buffer saline (PBS) twice. The suspension of cells was transferred to FACS tube, mixed with $10 \mu \mathrm{M}$ of $\mathrm{H}_{2}$ DCFDA (Invitrogen, Life Technologies, USA), further incubated at RT for $30 \mathrm{~min}$ and protected from light. The cell suspension was then subjected to a flow cytometer for ROS analysis. Intracellular ROS was quantitated using CellQuest $^{\mathrm{TM}}$ Pro software (BD Biosciences, San Jose, CA, USA).

\section{Caspase activity assay}

Cells were treated with the compounds for $6 \mathrm{~h}$. After treatment, the cells were harvested and washed twice in cold PBS. To extract protein, the cell pellet was lysed in lysis buffer and centrifuged at 13,000 rpm for $5 \mathrm{~min}$. The supernatant was collected and measured for protein content using DC-Bradford assay kit (Bio-rad Inc., USA).

Activities of caspase-3/7, caspase- 8 , and caspase-9 were determined using Caspase Colorimetric Activity Assay Kit (Millipore, USA) [27]. Briefly, $100 \mu \mathrm{g}$ protein was pipetted to a 96 -well plate $(70 \mu \mathrm{l})$, followed by $50 \mu \mathrm{l}$ reaction buffer, and $10 \mu \mathrm{l}$ substrate (IETD-pNA for caspase-8, LEHD-pNA for caspase-9, and DEVD-pNA for caspase-3). The mixture was incubated at $37{ }^{\circ} \mathrm{C}$ for 3 and $24 \mathrm{~h}$. Formation of $p$-nitroaniline was measured with an ELISA-microplate reader (Biochrom EZ Read 400, UK).

\section{AnnexinV-FITC/Propidium iodide double staining assay}

After that the cells were incubated with the compounds at various concentrations for $24 \mathrm{~h}$, they were trypsinized, collected, washed with PBS, and stained with Annexin V-FITC and propidium iodide (PI) according to the manufacturer's instructions (Roche Diagnostics Deutschland $\mathrm{GmbH}$, Mannheim, Germany). After staining, the stained cells were subjected to a flow cytometer (BD Biosciences 2 Laser FacsCalibur, USA) using FL-1 and FL-2. Percentages of Annexin V-FITC- and Annexin V-FITC/PI-positive cells were analyzed as apoptotic cells by CellQuest ${ }^{\mathrm{TM}}$ Pro (BD Biosciences) [23].

\section{Statistical analysis}

Data are expressed as mean \pm standard deviation (SD) from at least three independent experiments. Statistical comparisons were performed using Student's t-test for differences between two groups and by one-way ANOVA with Bonferroni Post Hoc test for differences among multiple groups. Significance was assigned for $p$ values $<0.05$ using GraphPad Prism 6.0 (GraphPad Software, USA).

\section{Results}

\section{Effect of trienone 11 on cell viability and cytotoxicity} in CLS-354 cells

Human oral squamous carcinoma cell lines CLS-354/DX and CLS-354/WT were established as in vitro models for drug responsiveness studies. CLS-354/DX cells were found to be more aggressive and more multidrug-resistant than CLS-354/WT [23, 24]. To examine responsiveness to curcumin, trienone $\mathbf{4}$, and trienone $\mathbf{1 1}$ (Fig. 1), we performed MTT assay after $24 \mathrm{~h}$ treatment of the three compounds at concentrations ranging from 0.01 to $80 \mu \mathrm{M}$. Cell proliferation of CLS-354/DX cells (Fig. 2a) and CLS-354/WT (Fig. 2b) was inhibited by curcumin, trienone $\mathbf{4}$, and trienone $\mathbf{1 1}$ in a dose-dependent manner. In both cell lines, cell viability drastically decreased by $70-75 \%$ upon treatment with $20 \mu \mathrm{M}$ of trienone 11 (Fig. 2a, b, lower panel) but not so with curcumin 

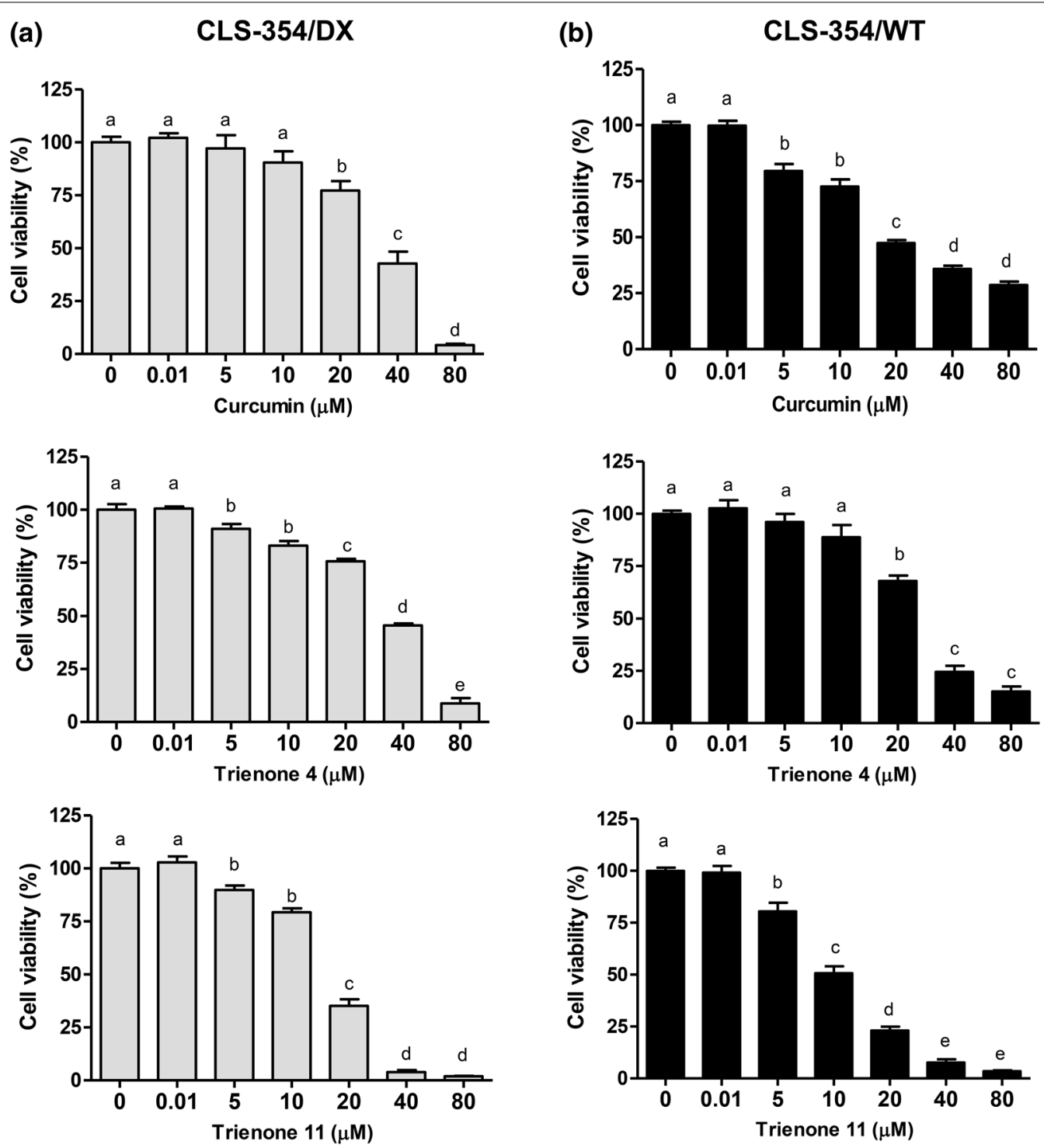

Fig. 2 The effects of curcumin, trienone $\mathbf{4}$, and trienone $\mathbf{1 1}$ on cell viability of human squamous cell carcinoma CLS-354/DX and CLS-354/WT cells. CLS-354/DX cells (a) and CLS-354/WT cells (b) were treated with 0.01- $80 \mu \mathrm{M}$ of curcumin, trienone $\mathbf{4}$, or trienone $\mathbf{1 1}$ for $24 \mathrm{~h}$. Cell viability was measured by MTT assay after treatment. Values are expressed as mean \pm standard deviation (SD) of duplicate samples in three independent experiments. Different letters above the bar indicate the significant difference $(p<0.05)$

(Fig. 2a, b, upper panel) and trienone 4 (Fig. 2a, b, middle panel), indicating comparatively low responsiveness to curcumin and trienone 4. Half-maximal inhibitory concentration $\left(\mathrm{IC}_{50}\right)$ and selectivity index $(\mathrm{SI})$ were examined to compare the potency and safety margin of the compounds. As shown in Table 1 , the $\mathrm{IC}_{50}$ concentrations of curcumin, trienone 4 , and trienone 11 observed in CLS-354/DX cells were $47.54 \pm 1.42,36.58 \pm 1.02$, and $16.50 \pm 1.03 \mu \mathrm{M}$, respectively, while $\mathrm{IC}_{50}$ values observed in CLS-354/WT were $13.31 \pm 1.24,23.81 \pm 1.03$, and $10.09 \pm 1.06 \mu \mathrm{M}$, respectively (Table 1$)$. DMSO $(<0.5 \%)$ was used as the treatment vehicle and did not affect cell viability. Results suggested that trienone $\mathbf{1 1}$ treatment provided a significantly greater $\mathrm{IC}_{50}$ value than curcumin (threefold) or trienone 4 (twofold) in CLS-354/DX cells $(p<0.05)$. This finding indicated that curcumin had low potential to inhibit multidrug-resistant cancer but was effective against CLS-354/WT which is non-aggressive. To evaluate the cytotoxicity of the three compounds against normal cells, African green monkey kidney cells (Vero cells) were tested as representative normal epithelial cells. We found that trienone $\mathbf{1 1}$ exerted cytotoxicity 
Table 1 The IC 50 and selectivity index (SI) of curcumin, trienone 4, and trienone 11 in CLS-354/DX and CLS-354/WT

\begin{tabular}{|c|c|c|c|c|c|}
\hline \multirow[t]{2}{*}{ Compound } & \multicolumn{3}{|l|}{$\mathrm{IC}_{50}(\mu \mathrm{M})$} & \multicolumn{2}{|c|}{ Selectivity index (SI) } \\
\hline & CLS-354/DX & CLS-354/WT & Vero & CLS-354/DX & CLS-354/WT \\
\hline Curcumin & $47.54 \pm 1.42^{\mathrm{aA}}$ & $13.31 \pm 1.24^{\mathrm{aB}}$ & $35.41 \pm 1.23^{a C}$ & 0.7 & 2.6 \\
\hline Trienone $\mathbf{4}$ & $36.58 \pm 1.02^{\mathrm{bA}}$ & $23.81 \pm 1.03^{\mathrm{bB}}$ & $>50^{b c}$ & 1.4 & 2.1 \\
\hline Trienone $\mathbf{1 1}$ & $16.50 \pm 1.03^{\mathrm{CA}}$ & $10.09 \pm 1.06^{\mathrm{CB}}$ & $33.89 \pm 6.83^{a c}$ & 2.0 & 3.4 \\
\hline
\end{tabular}

Values are expressed as mean \pm standard deviation (SD) of duplicate sample in three independent experiments. Different lower-case letters above values indicate statistically significant difference $(p<0.05)$ in the same column, and different upper-case letters above values indicate statistically significant difference $(p<0.05)$ in the same row

to Vero cells at the $\mathrm{IC}_{50}$ concentration of $33.89 \pm 6.83 \mu \mathrm{M}$, which was significantly weaker than the $\mathrm{IC}_{50}$ observed for both cancer cell lines. Moreover, trienone 11 provided the best selectivity index (SI) in both cell lines at 2.0 in CLS-354/DX and 3.4 in CLS-354/WT (Table 1). These data suggested trienone $\mathbf{1 1}$ as the most potent compound against CLS-354/DX cells.

\section{Effect of trienone 11 on apoptosis induction in CLS-354/ DX cells}

CLS-354/DX cells were exposed to trienone 11 for $24 \mathrm{~h}$ and changes in cell morphology were observed including cell floating, cell shrinkage, and blebbing (Additional file 1: Fig. S2) as associated characteristics of apoptotic cells. Apoptosis induction was then investigated using the Annexin V-fluorescein isothiocyanate (FITC)/propidium iodide (PI) staining method. Treatment with 15-30 $\mu \mathrm{M}$ of trienone 11 in CLS-354/DX cells for $24 \mathrm{~h}$ increased the proportions of Annexin V-FITC-positive cells (early apoptotic cells) from 2.57 to $11.60 \%$, and Annexin V-FITC-/PI positive cells (late apoptotic cells) from 10.01 to $27.64 \%$ (Fig. 3a), while total apoptosis in CLS-354/DX cells significantly increased to $40 \%$ of the total cell population (Fig. 3b). Early apoptotic and late apoptotic CLS-354/WT cells also increased from 7.24 to $17.52 \%$ and from 5.05 to $14.56 \%$, respectively (Fig. 3c), while total induced apoptosis rate was $30 \%$ (Fig. 3d). This data indicated that trienone $\mathbf{1 1}$ induced apoptosis, leading to CLS-354/DX cell death.

\section{Effect of trienone 11 on activation of caspases}

Caspases are a family of protease enzymes that play a significant role in programmed cell death by initiating two distinct apoptotic pathways as the death receptormediated (extrinsic) pathway or the mitochondrial-mediated (intrinsic) pathway [28]. Caspase- 9 and caspase-8 are key players in the intrinsic and extrinsic pathways, respectively. These two caspases subsequently activate caspase-3 or caspase-7 (executioner), contributing to degradation of cellular components for apoptosis [29]. To investigate whether caspase was involved in apoptosis, we measured the catalytic activities of the caspases. The cells were exposed to trienone $\mathbf{1 1}$ for $6 \mathrm{~h}$. After that, catalytic activities of caspase-3/7, caspase- 8 , and caspase- 9 were monitored in the cell lysate at 3 and $24 \mathrm{~h}$. Results showed that catalytic activity of caspase-3/7 was rapidly elevated within $3 \mathrm{~h}$ at 3.3-fold compared to basal level. After $24 \mathrm{~h}$ of incubation, activities of caspase-3/7, caspase- 8 , and caspase- 9 significantly increased by $5.2-$, 2.0- and 1.9-fold, respectively (Fig. 4). Thus, trienone 11 induced apoptosis in CLS-354/DX cells through both intrinsic and extrinsic pathways.

\section{Effect of trienone 11 on intracellular ROS production}

ROS are well-known signaling molecules that play a pivotal role in controlling cell death as well as cell survival. Here, intracellular ROS levels were examined after trienone treatment. Results indicated that trienone $\mathbf{1 1}$ at 15 and $30 \mu \mathrm{M}$ increased ROS levels in CLS-354/DX cells dose-dependently, as shown by right-shifted signals (Fig. 5a). Elevated intracellular ROS levels significantly increased 1.5- and 3.1-fold after treatment with 15 and $30 \mu \mathrm{M}$ of trienone 11, respectively (Fig. 5b). Furthermore, $\mathrm{N}$-acetyl cysteine (NAC), an antioxidant, was used as a ROS inhibitor to confirm trienone 11-induced ROS formation in CLS-354/DX cells. We found that NAC treatment reversed ROS levels to the basal level (Fig. 5a, b), suggesting that trienone $\mathbf{1 1}$ had ROS-inducing potency. We further compared the ROS-inducing potency between trienone $\mathbf{1 1}$ and trienone $\mathbf{4}$. Results determined that trienone $\mathbf{4}$ was not able to induce ROS (Additional file 1: Fig. S3), while trienone $\mathbf{1 1}$ was successful.

\section{Involvement of ROS in trienone 11-induced apoptosis}

To further demonstrate the involvement of ROS in caspase activation and its anti-proliferative effects, we determined whether NAC prevented caspase catalytic activity and cell death in CLS-354/DX cells. All caspase catalytic activities significantly increased after trienone $\mathbf{1 1}$ treatment at 2-5-fold from the basal level (Fig. 6). When the cells were exposed to trienone $11(30 \mu \mathrm{M})$ in the presence of NAC ( $5 \mathrm{mM})$ for $6 \mathrm{~h}$, catalytic activities of caspase- $3 / 7$ and caspase- 9 significantly reduced, similar to 


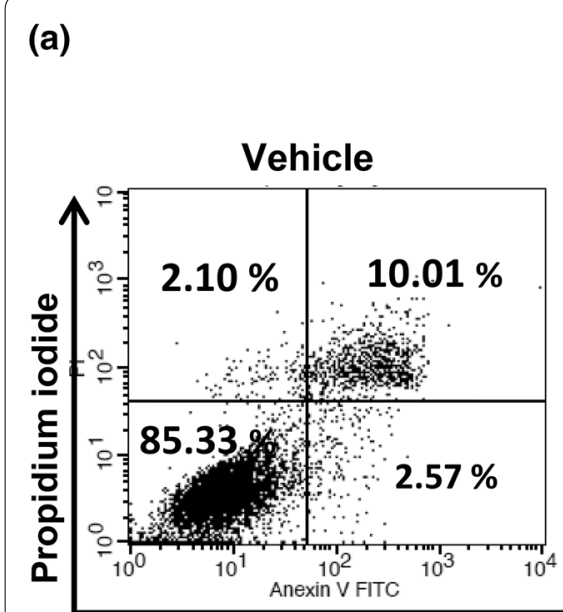

\section{CLS-354/DX}
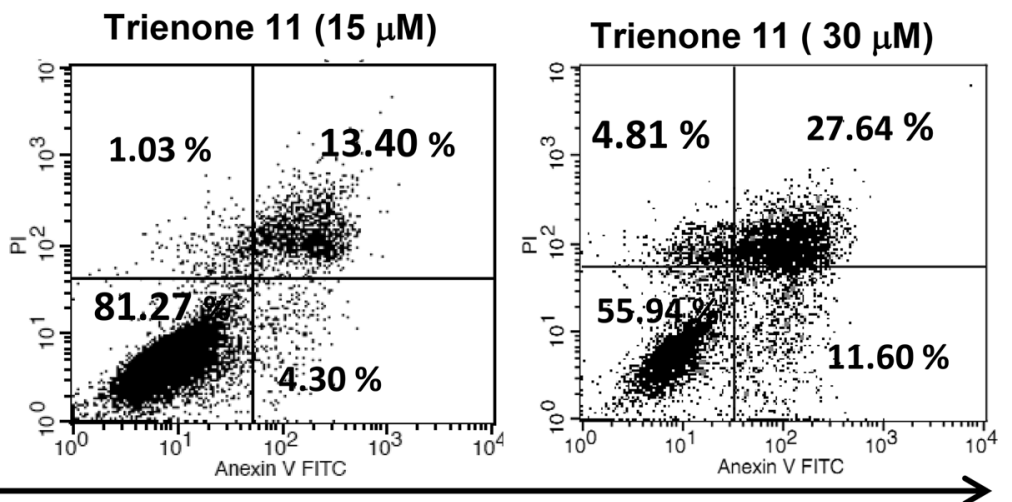

Annexin V-FITC

(b)

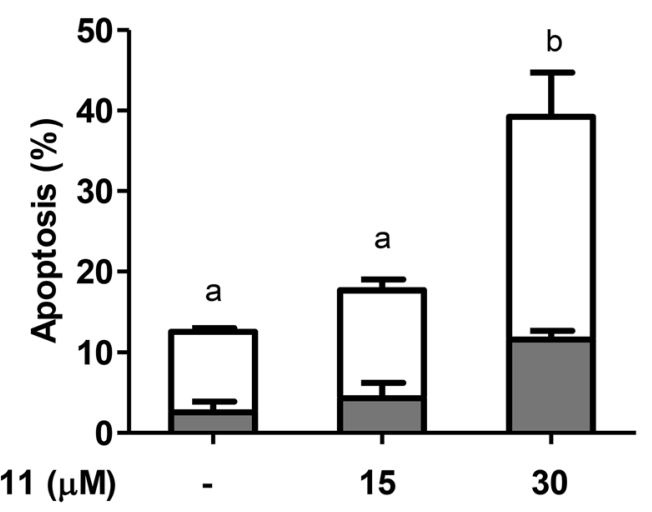

$\square$ Early apoptotic cells

$\square$ Late apoptotic cells

\section{CLS-354/WT}

(c)

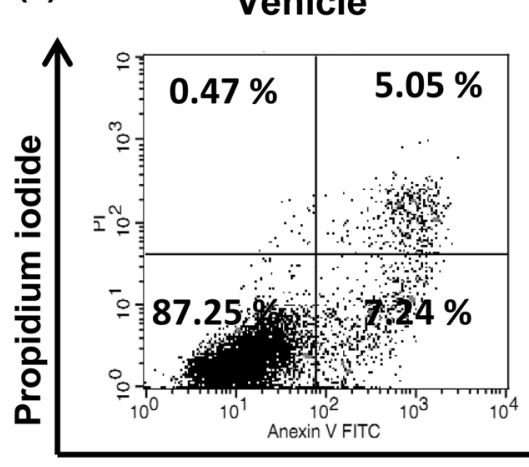

Trienone $11(15 \mu \mathrm{M})$

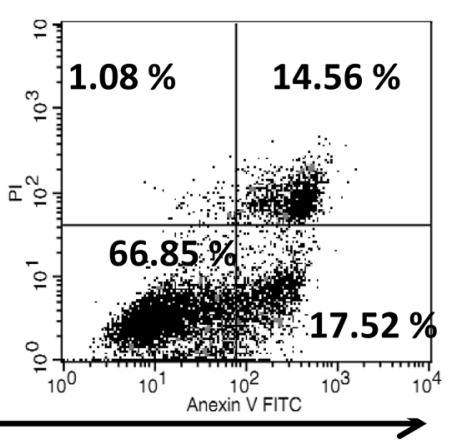

Annexin V-FITC

(d)

Early apoptotic cells $\square$ Late apoptotic cells

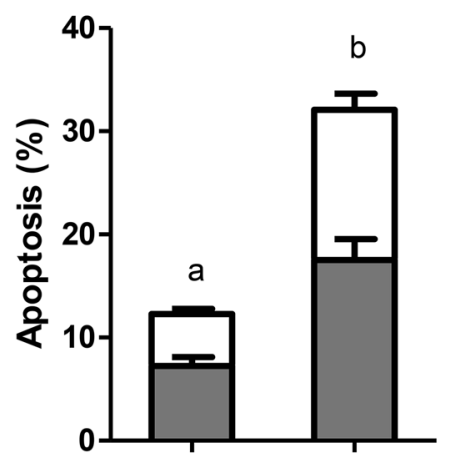

15

Fig. $\mathbf{3}$ The effects of trienone $\mathbf{1 1}$ on the induction of apoptosis in CLS-354/DX and CLS-354/WT cells. CLS-354/DX cells (a, b) and CLS-354/WT (c, d) were treated with trienone 11 at $15-30 \mu \mathrm{M}$ and $15 \mu \mathrm{M}$, respectively, for $24 \mathrm{~h}$. Apoptosis was determined by flow cytometric analysis using double staining with Annexin V-FITC and propidium iodide, and the results are represented as scatter plots $(\mathbf{a}, \mathbf{c})$ and as percentages of apoptotic cells $(\mathbf{b}$, d). Values are expressed as mean \pm standard deviation (SD) of duplicate samples in three independent experiments. Different letters above the bar indicate the significant difference $(p<0.05)$ 


\section{Vehicle Trienone 11}
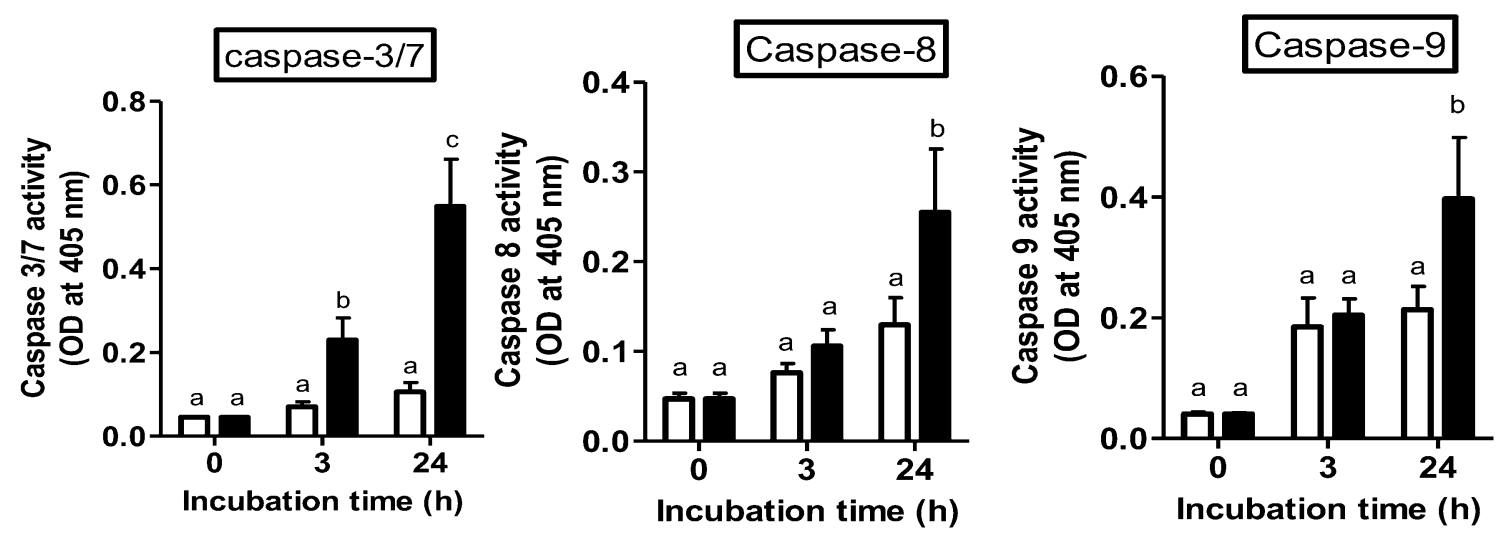

Fig. 4 The effects of trienone $\mathbf{1 1}$ on the activation of caspase-3/7, caspase-8, and caspase-9 in CLS-354/DX cells. The cells were treated with trienone $11(30 \mu \mathrm{M})$ for $6 \mathrm{~h}$. After treatment, protein lysates (100 $\mathrm{\mu g}$ protein) were incubated with the substrates of caspase-3/7, caspase-8, and caspase- 9 for indicated times at $37^{\circ} \mathrm{C}$ for 3 and $24 \mathrm{~h}$. Activities of caspase-3/7 (a), caspase-8 (b), and caspase-9 (c) were measured by a microplate reader. Values are expressed as mean \pm standard deviation (SD) from four independent treatments. Different letters above the bar indicate the significant difference $(p<0.05)$

observation levels in untreated cells (Fig. 6a). Furthermore, the presence of NAC (2.5-10 $\mathrm{mM})$ completely prevented trienone 11-induced cell death with significantly increased cell viability from 50 to $90 \%$ (Fig. 6b). These findings indicated that ROS induced by trienone $\mathbf{1 1}$ was decisively involved in the mitochondrial-mediated (intrinsic) pathway of apoptosis.

\section{Discussion}

Extensive studies have demonstrated that curcumin exhibits various biological activities including anticancer activity [7-10]; however, curcumin had moderate-to-low cytotoxic efficacy against human cancer cells due to its poor bioavailability $[11,12]$. Recently, structural modification of curcumin has offered a potential approach for optimizing new leads for anticancer drug development [30]. Structural modification studies of curcumin have suggested $\beta$-diketone moiety as the position leading to chemical instability, while modification to mono-ketone moiety improved stability as well as cytotoxicity [31]. Accordingly, curcuminoid analogs exerting mono-ketone moiety such as trienones could be used as curcuminbased leads for anticancer drug development. Trienones are found in very small amounts in nature [18] but some have been synthesized in the laboratory by various methods including key fragment substituted 4-phenylbut-3-en-2-ones and 3-phenylacrylaldehydes [17], dehydrogenation of the enone with 2,3-dichloro-5,6-dicyano-1,4-benzoquinone and THF [22], and Wittig reaction and aldol condensation [32], thereby overcoming the limitation of trienone preparation.
Several trienones and modified analogs have demonstrated more potent cytotoxicity than curcumin toward cancer cells including melanoma cells (B16F10) [21], prostate cancer cells (PC-3, DU-45, and LNCaP) [32], cervical cancer cells (HeLa) [32] and the KB cell line [17]. Recently, we found that trienone $\mathbf{1 1}$ as modified trienone 4 exerted the highest cytotoxic potency in KB cells [17]. Here, trienone $\mathbf{1 1}$ was investigated for its anticancer effect against the multidrug-resistant OSCC cell line CLS-354/DX and the parental cell line CLS-354/WT in comparison to curcumin and trienone 4 . We found that curcumin poorly inhibited multidrug-resistant cancer cells with the high $\mathrm{IC}_{50}$ at $47.54 \mu \mathrm{M}$, whereas curcumin was still active in parental cells with $\mathrm{IC}_{50}$ at $13.31 \mu \mathrm{M}$. This occurred because CLS-354/DX cells are more aggressive than CLS-354/WT cells by expressing multidrug-resistant protein (MRP), increased drug pump activity, and reduced redox status [22, 23]. As expected, trienone 11 was more potent than both trienone $\mathbf{4}$ and curcumin in inhibiting cell growth in CLS-354/DX cells, similar to results for KB cells in our previous report [17]. Interestingly, the $\mathrm{IC}_{50}$ of trienone 11 inhibiting CLS-354/ DX cells $(16.5 \mu \mathrm{M})$ indicated higher potency than cisplatin (a platinum-based anticancer drug) $(33.2 \mu \mathrm{M})$ [22] This finding suggested the notion that trienone $\mathbf{1 1}$ may be useful for eliminating multidrug-resistant cancer cells.

Several studies reported that curcuminoids induced apoptotic cell death by increasing the intracellular ROS level over the threshold in OSCC cell lines [33-35]. Similar to our observation, trienone $\mathbf{1 1}$ treatment increased intracellular ROS levels and cell death which could be 

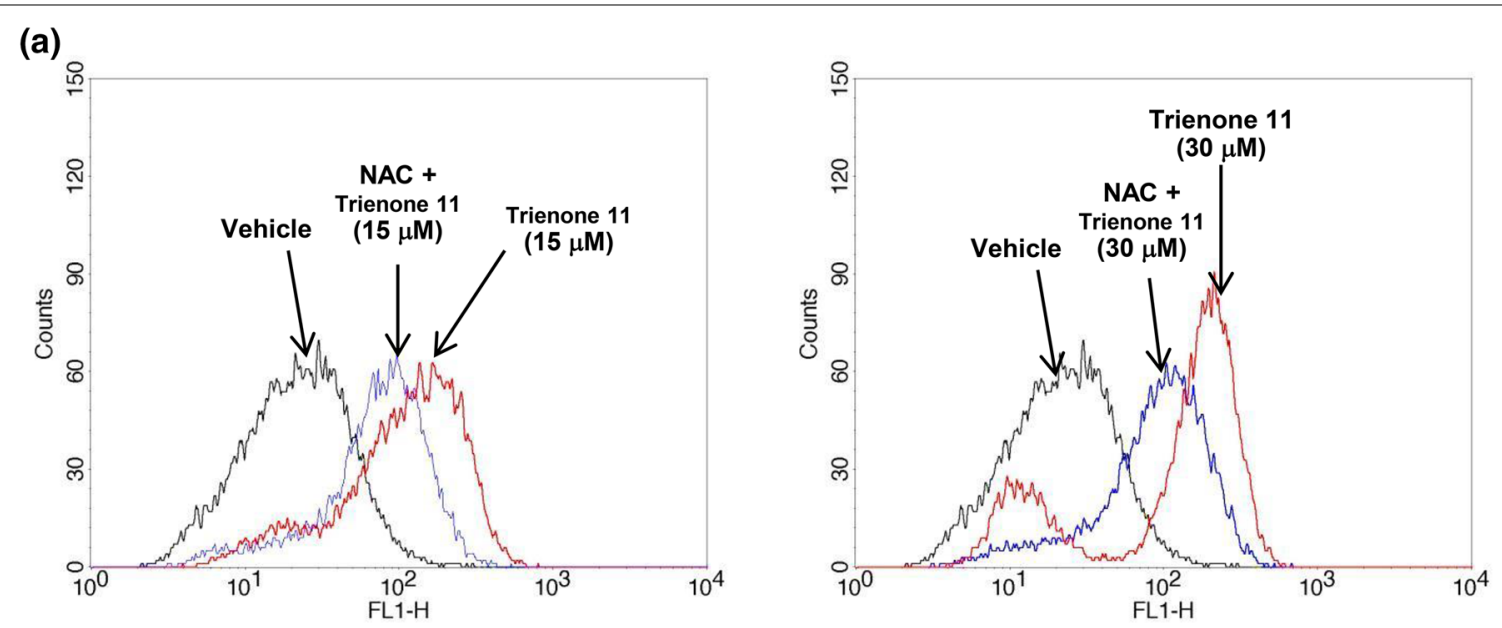

(b)

\section{CLS-354/DX}

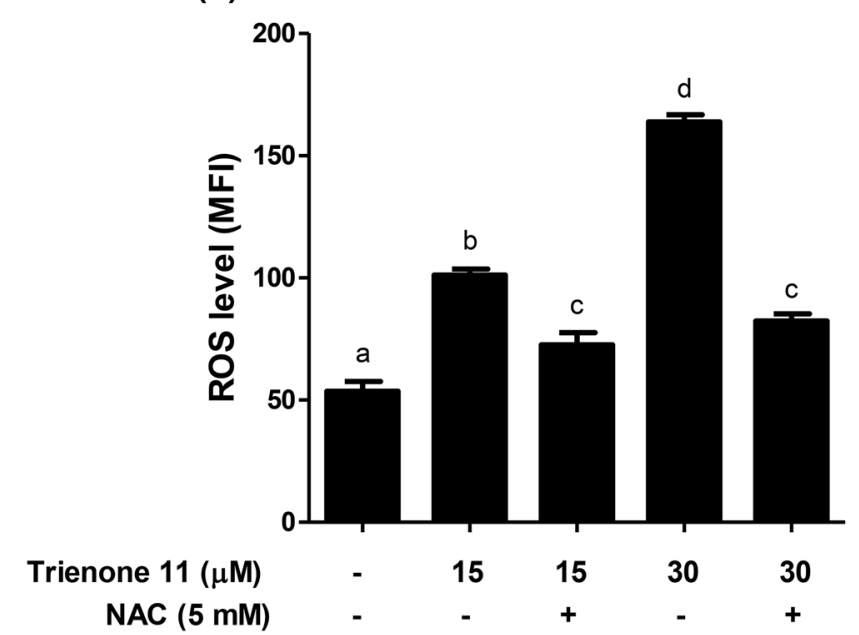

Fig. 5 The effects of trienone $\mathbf{1 1}$ on production of reactive oxygen species (ROS) in CLS-354/DX cells. CLS-354/DX cells were treated with 15-30 $\mu \mathrm{M}$ trienone 11 for $12 \mathrm{~h}$ with/without $5 \mathrm{mM} \mathrm{N}$-acetyl cysteine (NAC) pre-treatment. Intracellular ROS was detected using $\mathrm{H}_{2}$ DCFDA probe followed by flow cytometric analysis. ROS levels are represented in a histogram (a) and mean \pm standard deviation (SD) of fluorescent intensities (MFI) (b). Values are expressed as mean \pm standard deviation (SD) of duplicate samples in three independent experiments. Different letters above the bar indicate the significant difference $(p<0.05)$

reversed by supplementation with NAC, indicating ROSmediated cell death. ROS-metabolic enzymes have been proposed as the main biological targets of curcuminoids. Curcuminoids and analogs can bind to several ROS-metabolic enzymes including carbonyl reductase 1, glutathione-S-transferase, glyoxalase I, NAD(P)H dehydrogenase, quinone 1 , and thioredoxin reductase 1 (TrxR1), thereby inactivating the enzymes and leading to ROS accumulation [16, 36]. Additionally, a differential ROS-inducing ability was related, in part, to the compound's structure. Trienone $\mathbf{1 1}$ possesses the free phenolic hydroxyl group at the meta-position which can activate stronger oxidation than analogs having a methoxy group [17]. This may induce mitochondrial membrane damage and subsequently mitochondrial ROS leakage.

When the ROS level climbs above cellular tolerability thresholds, excessive ROS causes oxidative damage to deoxyribonucleic acid (DNA), lipids, and proteins, leading to activation of cell death processes mainly as the mitochondrial pathway of apoptosis [37]. Initially, damaged DNA leads to activation of p53 protein and the p53 signaling pathway to upregulate pro-apoptotic proteins and downregulate anti-apoptotic proteins in the mitochondria. Overexpression of pro-apoptotic Bax induces cytochrome $\mathrm{c}$ release from the mitochondria to form complexes with Apaf- 1 and caspase- 9 that consequently activate caspase-3 and apoptosis [37]. ROS-derived curcuminoid treatment causes DNA damage, change in 
(a)

\section{Caspase-3/7}

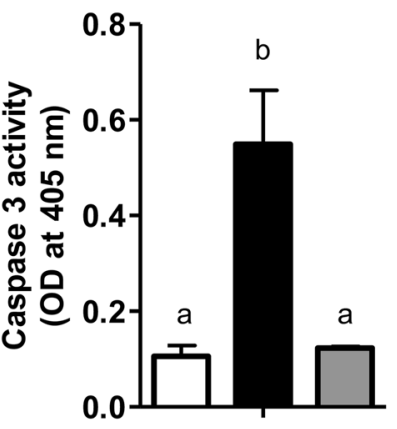

Trienone 11

NAC (b)

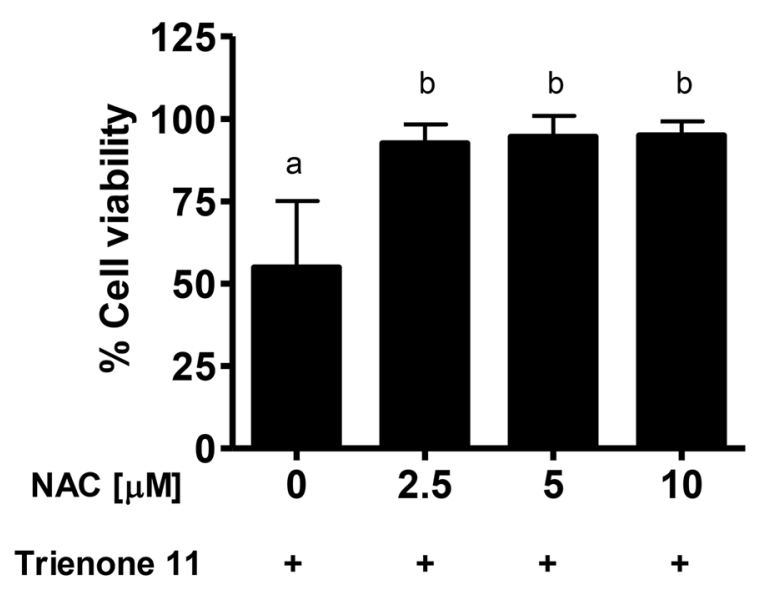

(c)

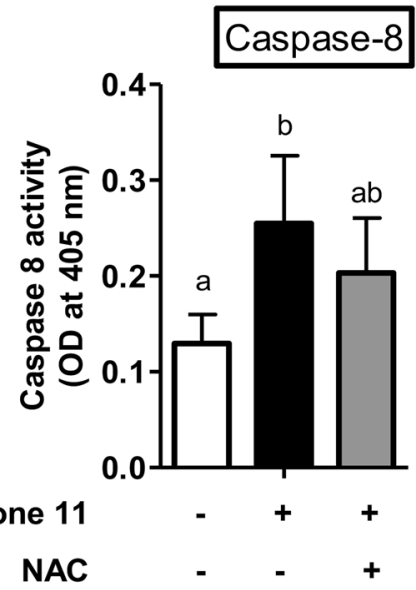

Caspase-9

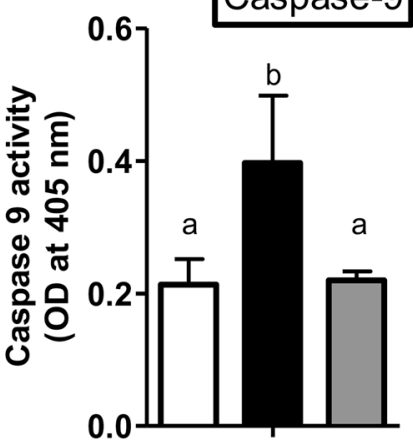

Trienone 11

NAC

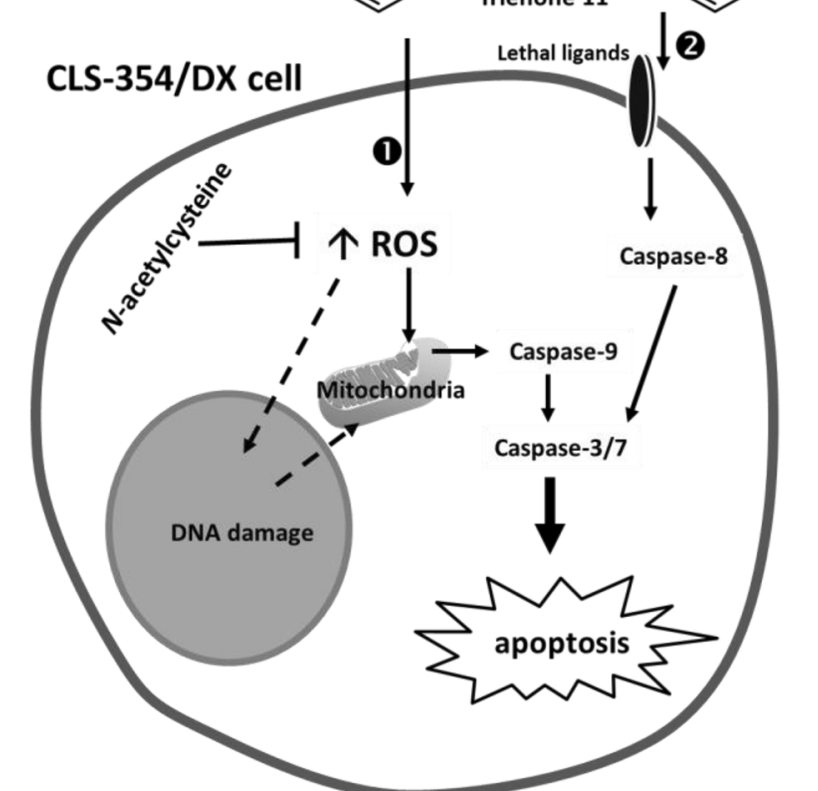

Fig. 6 Trienone 11-induced cell death is ROS mediated and caspase-3/7, -9 dependent in CLS-354/DX. The activities of caspase-3/7, -8 , and -9 of CLS-354/DX cells upon pre-treatment with $5 \mathrm{mM} \mathrm{N}$-acetyl cysteine (NAC), followed by $30 \mu \mathrm{M}$ trienone $\mathbf{1 1}$ for $12 \mathrm{~h}$ (a). Values are expressed as mean \pm standard deviation (SD) from four independent treatments. Cell viability (b) of CLS-354/DX cells upon pre-treatment with NAC at the indicated concentrations and trienone $11(30 \mu \mathrm{M})$ treatment for $24 \mathrm{~h}$ was measured using MTT assay. Values are expressed as mean \pm standard deviation (SD) of triplicate samples in three independent experiments. Different letters above the bar indicate the significant difference $(p<0.05)$. The proposed cytotoxic mechanism (c) of trienone $\mathbf{1 1}$ in CLS-354/DX cells; $\mathbf{1}$ trienone $\mathbf{1 1}$ markedly induced intracellular ROS production, which may directly damage mitochondria or DNA resulting in caspase-9 and -3/7 activation through intrinsic pathway of apoptosis; (2) trienone 11 can trigger extrinsic pathway of apoptosis via ROS-independent caspase-8 activation

mitochondrial membrane potential (MMP), increased expression of pro-apoptotic proteins and decreased expression of anti-apoptotic proteins, leading to caspase-9 and -3 activation in oral cancer SAS cells [33]. Thus, caspase- 9 and -3 activation could be an indicator of the mitochondrial pathway of apoptosis. Our results showed that ROS-derived trienone $\mathbf{1 1}$ revealed activation of caspase- 9 and caspase-3, suggesting that trienone $\mathbf{1 1}$ might induce apoptosis through a mitochondrial pathway [36]. Furthermore, curcumin has also been reported to induce apoptosis via a Fas receptor/caspase-8 or extrinsic pathway [38]. Consistent with our findings, trienone 
11 also increased caspase-8 catalytic activity; however, it is ROS-independent. Trienone $\mathbf{1 1}$ may interact with the Fas receptor and form a complex on the cell surface that directly triggers a signaling cascade to activate caspase- 8 . The proposed cytotoxic mechanism of trienone $\mathbf{1 1}$ in CLS-354/DX cells is illustrated in Fig. 6c.

Our studies are the first to indicate that the trienone 11 analog of curcumin shows promise as a potent cytotoxic agent, more powerful than curcumin and the natural trienone 4 against the multidrug-resistant OSCC cell line CLS-354/DX. The compound induced apoptotic cell death via ROS and caspase- $3 / 7,-8$, and -9 activations. We also demonstrated the mechanism by which trienone $\mathbf{1 1}$ activates ROS to mediate caspase activation and eventually apoptosis via the intrinsic pathway. To further develop trienone $\mathbf{1 1}$ as an effective anticancer agent for OSCCs, the therapeutic potential of an in vivo model, as well as the main molecular targets, require a more detailed and comprehensive analysis.

\section{Supplementary information}

Supplementary information accompanies this paper at https://doi. org/10.1186/s13765-020-0491-8.

Additional file 1. ${ }^{1} \mathrm{H}$ and ${ }^{13} \mathrm{C}$ NMR spectra of compounds (Fig. S1), cell morphology (Fig. S2), and intracellular ROS levels in CLS-354/DX cells upon treatment with trienone 4 (Fig. S3).

\section{Acknowledgements}

We would like to thank Assoc. Prof. Dr. Seppo Karrila for English language editing and reviewing of this article.

\section{Authors' contributions}

TU, TC, WC, performed experiments and wrote the paper. PB and AS helped the preparation of experiments. TU, WC, AS, PB revised the manuscript. AS, WC supervised the work. All authors read and approved the final manuscript.

\section{Funding}

This work was supported by the Faculty of Science and Technology Research Fund, Prince of Songkla University, Pattani Campus, Contract no. SAT610461S and The Thailand Research Fund, Contract no. DBG6180030.

\section{Availability of data and materials}

Not applicable.

\section{Competing interests}

The authors declare that they have no competing interests.

\begin{abstract}
Author details
${ }^{1}$ Department of Pre-Clinic, Faculty of Science and Technology, Prince of Songkla University, Pattani Campus, Pattani 94000, Thailand. ${ }^{2}$ Department of Food Science and Nutrition, Faculty of Science and Technology, Prince of Songkla University, Pattani Campus, Pattani 94000, Thailand. ${ }^{3}$ Department of Chemistry and Center of Excellence for Innovation in Chemistry, Faculty of Science, Ramkhamhaeng University, Bangkok 10240, Thailand. ${ }^{4}$ Department of Chemistry, Faculty of Science, Siam University, Bangkok 10160, Thailand. ${ }^{5}$ School of Allied Health Sciences and Research Institute for Health Science, Walailak University, Nakhon Si Thammarat 80161, Thailand.
\end{abstract}

Received: 31 October 2019 Accepted: 17 January 2020 Published online: 03 February 2020

\section{References}

1. Massano J, Regateiro FS, Januário G, Ferreira A (2006) Oral squamous cell carcinoma: review of prognostic and predictive factors. Oral Surg Oral Med Oral Pathol Oral Radiol Endod 102(1):67-76

2. Warnakulasuriya S (2009) Global epidemiology of oral and oropharyngeal cancer. Oral Oncol 45(4-5):309-316

3. Chang CW, Chen YS, Chou SH, Han CL, Chen YJ, Yang CC, Huang CY, Lo JF (2014) Distinct subpopulations of head and neck cancer cells with different levels of intracellular reactive oxygen species exhibit diverse stemness, proliferation, and chemosensitivity. Cancer Res 74(21):6291-6305

4. $\quad$ Wang C, Liu XQ, Hou JS, Wang JN, Huang HZ (2016) Molecular mechanisms of chemoresistance in oral cancer. Chin J Dent Res. 19(1):25-33

5. Saraswathy M, Gong S (2013) Different strategies to overcome multidrug resistance in cancer. Biotechnol Adv 31(8):1397-1407

6. Xiao Z, Morris-Natschke SL, Lee KH (2016) Strategies for the optimization of natural leads to anticancer drugs or drug candidates. Med Res Rev 36(1):32-91

7. Ghosh S, Banerjee S, Sil PC (2015) The beneficial role of curcumin on inflammation, diabetes and neurodegenerative disease: a recent update. Food Chem Toxicol 83:111-124

8. Trujillo J, Chirino Yl, Molina-Jijón E, Andérica-Romero AC, Tapia E, PedrazaChaverrí J (2013) Renoprotective effect of the antioxidant curcumin: recent findings. Redox Biol. 1:448-456

9. Aggarwal BB, Kumar A, Bharti AC (2003) Anticancer potential of curcumin preclinical and clinical studies. Anticancer Res 23(1A):363-398

10. Kunnumakkara AB, Bordoloi D, Harsha C, Banik K, Gupta SC, Aggarwal BB (2017) Curcumin mediates anticancer effects by modulating multiple cell signaling pathways. Clin Sci 131(15):1781-1799

11. Kharat M, Du Z, Zhang G, McClements DJ (2017) Physical and chemical stability of curcumin in aqueous solutions and emulsions: impact of $\mathrm{pH}$, temperature, and molecular environment. J Agric Food Chem 65(8):1525-1532

12. Anand P, Kunnumakkara AB, Newman RA, Aggarwal BB (2007) Bioavailability of curcumin: problems and promises. Mol Pharm 4(6):807-818

13. Aziz MNM, Hussin Y, Che Rahim NF, Nordin N, Mohamad NE, Yeap SK et al (2018) Curcumin analog DK1 induces apoptosis in human osteosarcoma cells in vitro through mitochondria-dependent signaling pathway. Molecules. https://doi.org/10.3390/molecules23010075

14. Chen X, Chen X, Zhang X, Wang L, Cao P, Rajamanickam V et al (2019) Curcuminoid B63 induces ROS-mediated paraptosis-like cell death by targeting TrxR1 in gastric cells. Redox Biol. 21:101061

15. He Y, Li W, Hu G, Sun H, Kong Q (2018) Bioactivities of EF24, a novel curcumin analog: a review. Front Oncol. 8:614

16. He W, Xia Y, Cao P, Hong L, Zhang T, Shen X et al (2019) Curcuminoid WZ35 synergize with cisplatin by inducing ROS production and inhibiting TrxR1 activity in gastric cancer cells. J Exp Clin Cancer Res. 38(1):207

17. Chuprajob T, Changtam C, Chokchaisiri R, Chunglok W, Sornkaew N, Suksamrarn A (2014) Synthesis, cytotoxicity against human oral cancer KB cells and structure-activity relationship studies of trienone analogues of curcuminoids. Bioorg Med Chem Lett 24(13):2839-2844

18. Nakayama R, Tamura Y, Yamanaka H, Kikuzaki H, Nakatani N (1993) Two curcuminoid pigments from Curcuma domestica. Phytochemistry 33(2):501-502

19. Mohamad H, Lajis NH, Abas F, Ali AM, Sukari MA, Kikuzaki H, Nakatani N (2005) Antioxidative constituents of Etlingera elatior. J Nat Prod 68(2):285-288

20. Jang MK, Sohn DH, Ryu JH (2001) A curcuminoid and sesquiterpenes as inhibitors of macrophage TNF-alpha release from Curcuma zedoaria. Planta Med 67(6):550-552

21. Lo CY, Liu PL, Lin LC, Chen YT, Hseu YC, Wen ZH, Wang HM (2013) Antimelanoma and antityrosinase from Alpinia galangal constituents. ScientificWorldJournal. 2013:186505

22. Changtam C, de Koning HP, Ibrahim H, Sajid MS, Gould MK, Suksamrarn A (2010) Curcuminoid analogs with potent activity against Trypanosoma and Leishmania species. Eur J Med Chem 45(3):941-956

23. Utaipan T, Athipornchai A, Suksamrarn A, Chunsrivirot S, Chunglok W (2017) Isomahanine induces endoplasmic reticulum stress and simultaneously triggers p38 MAPK-mediated apoptosis and autophagy in multidrug-resistant human oral squamous cell carcinoma cells. Oncol Rep 37(2):1243-1252 
24. Utaipan T, Sattayakhom A, Prachongsai I, Charong N, Chunglok W (2018) Reduction of intracellular-reactive oxygen species and diminished mitogen-activated protein kinases (MAPKs) activation are associated with oral squamous cell carcinoma cell aggressiveness. Walailak J Sci Technol 15(2):131-141

25. Peña-Morán OA, Villarreal ML, Álvarez-Berber L, Meneses-Acosta A, Rodríguez-López V (2016) Cytotoxicity, post-treatment recovery, and selectivity analysis of naturally occurring podophyllotoxins from Bursera fagaroides var. fagaroides on breast cancer cell lines. Molecules. https:// doi.org/10.3390/molecules21081013

26. Zhang X, Chen M, Zou P, Kanchana K, Weng Q, Chen W et al (2015) Curcumin analog WZ35 induced cell death via ROS-dependent ER stress and G2/M cell cycle arrest in human prostate cancer cells. BMC Cancer. 15:866

27. McStay GP, Green DR (2014) Assaying caspase activity in vitro. Cold Spring Harb Protoc. 2014(7):774-777

28. Fulda S, Debatin KM (2006) Extrinsic versus intrinsic apoptosis pathways in anticancer chemotherapy. Oncogene 25(34):4798-4811

29. Zimmermann KC, Bonzon C, Green DR (2001) The machinery of programmed cell death. Pharmacol Ther 92(1):57-70

30. Mbese Z, Khwaza V, Aderibigbe BA (2019) Curcumin and its derivatives as potential therapeutic agents in prostate, colon and breast cancers. Molecules. https://doi.org/10.3390/molecules24234386

31. Thakur A, Manohar S, Gerena CE, Zayas B, Kumar V, Malhotra SV, Rawat DS (2014) Novel 3,5-bis(arylidiene)-4-piperidone based monocarbonyl analogs of curcumin: anticancer activity evaluation and mode of action study. MedChemComm. 5(5):576-586

32. Wang R, Zhang X, Chen C, Chen G, Zhong Q, Zhang Q et al (2016) Synthesis and evaluation of 1,7-diheteroarylhepta-1,4,6-trien-3-ones as curcumin-based anticancer agents. Eur J Med Chem 110:164-180
33. Hsiao YT, Kuo CL, Chueh FS, Liu KC, Bau DT, Chung JG (2018) Curcuminoids induce reactive oxygen species and autophagy to enhance apoptosis in human oral cancer cells. Am J Chin Med 46(5):1145-1168

34. Kim JY, Cho TJ, Woo BH, Choi KU, Lee CH, Ryu MH, Park HR (2012) Curcumin-induced autophagy contributes to the decreased survival of oral cancer cells. Arch Oral Biol 57(8):1018-1025

35. Chang PY, Peng SF, Lee CY, Lu CC, Tsai SC, Shieh TM et al (2013) Curcuminloaded nanoparticles induce apoptotic cell death through regulation of the function of MDR1 and reactive oxygen species in cisplatin-resistant CAR human oral cancer cells. Int J Oncol 43(4):1141-1150

36. Larasati YA, Yoneda-Kato N, Nakamae I, Yokoyama T, Meiyanto E, Kato JY (2018) Curcumin targets multiple enzymes involved in the ROS metabolic pathway to suppress tumor cell growth. Sci Rep. 8(1):2039

37. Yang Y, Karakhanova S, Hartwig W, D'Haese JG, Philippov PP, Werner J, Bazhin AV (2016) Mitochondria and mitochondrial ROS in cancer: novel targets for anticancer therapy. J Cell Physiol 231(12):2570-2581

38. Bush JA, Cheung KJ Jr, Li G (2001) Curcumin induces apoptosis in human melanoma cells through a Fas receptor/caspase-8 pathway independent of p53. Exp Cell Res 271(2):305-314

\section{Publisher's Note}

Springer Nature remains neutral with regard to jurisdictional claims in published maps and institutional affiliations.

\section{Submit your manuscript to a SpringerOpen ${ }^{\circ}$ journal and benefit from:}

- Convenient online submission

- Rigorous peer review

- Open access: articles freely available online

- High visibility within the field

- Retaining the copyright to your article

Submit your next manuscript at $\boldsymbol{\nabla}$ springeropen.com 